\title{
Effect of Chemical Refining Steps on the Some Micro and Macro Element Content and Quality Parameters in Corn Oil
}

\begin{tabular}{|c|c|}
\hline ARTICLE INFO & A B S T R A C T \\
\hline $\begin{array}{l}\text { Keywords: } \\
\text { Chemically refining } \\
\text { Heavy metal } \\
\text { Food safety } \\
\text { Food quality } \\
\text { Corn oil }\end{array}$ & $\begin{array}{l}\text { In this study, it was aimed to determine some element contents and some quality properties and to } \\
\text { compare these parameters at each stage in the chemically refining process of crude corn oil. Color } \\
\text { (lovibond tintometer), free fatty acidity, peroxide values and fatty acid compositions were determined } \\
\text { in the samples of corn oil taken from consecutive stages of chemically refining. Also, the content of } \\
\text { elements ( } \mathrm{Na}, \mathrm{Mg}, \mathrm{K}, \mathrm{Ca}, \mathrm{Fe}, \mathrm{Pb}, \mathrm{Cd}, \mathrm{Ni}, \mathrm{Mn}, \mathrm{Zn}, \mathrm{Co}, \mathrm{Cr}, \mathrm{P}, \mathrm{Cu} \text { ) was analyzed, by using inductively- } \\
\text { coupled plasma-mass spectrometry (ICP-MS) and inductively-coupled plasma-optical emission } \\
\text { spectrometry (ICP-OES) after microwave digestion. The color (Lovibond tintometer), free fatty } \\
\text { acidity and peroxide values in the chemically refining process varied between } 2.7-16, \% 0.09-2.12 \text {, } \\
10.95-1.08 \mathrm{mEqO} / \mathrm{kg}, \text { respectively. Oleic, linoleic and linolenic acid contents changed between } \\
30.486-30.580 \%, 54.339-54.703 \% \text { and } 0.972-0.993 \% \text {, respectively, in the chemically refining stages. } \\
\text { While no trans fatty acids detected in crude corn oil and after degumming-neutralization step, very } \\
\text { low amount of trans oleic acid }(0.040 \% \text { ) and total trans linoleic acid ( } 0.132 \% \text { ) was detected in } \\
\text { bleached corn oil. The total trans fatty acid content little more increased in the last stage of the } \\
\text { chemically refining. However, total trans fatty acid content of refined corn oil was < } 0.3 \% \text {. It was } \\
\text { clearly seen that Na, Mg, } \mathrm{K}, \mathrm{P}, \mathrm{Ca}, \mathrm{Mn}, \mathrm{Fe}, \mathrm{Pb}, \mathrm{Ni}, \mathrm{Cr} \text {, Cu element contents decreased significantly } \\
\text { at the end of the chemically refining process. Although } \mathrm{Cd} \text {, Co and Zn elements were determined in } \\
\text { crude corn oil, these elements were not detected in the refined corn oil. The results obtained showed } \\
\text { that the chemically refining process effected some of the quality properties of corn oil and especially } \\
\text { the changes in the element contents. }\end{array}$ \\
\hline
\end{tabular}

Türk Tarım - Gıda Bilim ve Teknoloji Dergisi, 9(6): 982-990, 2021

\section{Kimyasal Rafinasyon Aşamalarının Mısır Yağındaki Bazı Mikro ve Makro Element Içeriği ve Kalite Parametrelerine Etkisi}

\begin{tabular}{|c|c|}
\hline M A K A L E B İ L G İ S İ & Ö Z \\
\hline $\begin{array}{l}\text { Anahtar Kelimeler: } \\
\text { Kimyasal rafinasyon } \\
\text { Ağır metal } \\
\text { Gıda güvenliği } \\
\text { Gıda kalitesi } \\
\text { Misır Yağ1 }\end{array}$ & $\begin{array}{l}\text { Bu çalışmada, ham mısır yağının kimyasal rafinasyon prosesi sürecinde bazı element içerikleri ile bazı kalite } \\
\text { özelliklerinin belirlenmesi ve bu parametrelerin her rafinasyon aşamasında karşılaştırılması amaçlandı. } \\
\text { Kimyasal rafinasyonun aşamalarından alınan mısır yağı örneklerinde renk (lovibond tintometre), serbest } \\
\text { yağ asitliği, peroksit değerleri ve yağ asidi bileşimleri tespit edildi. İlave olarak, indüktif eşleşmiş } \\
\text { plazma/optik emisyon spektroskopisi (ICP-OES) ve indüktif eşleşmiş plazma/kütle spektroskopisi (ICP- } \\
\mathrm{MS} \text { ) cihazlarında element ( } \mathrm{Na}, \mathrm{Mg}, \mathrm{K}, \mathrm{Ca}, \mathrm{Fe}, \mathrm{Pb}, \mathrm{Cd}, \mathrm{Ni}, \mathrm{Mn}, \mathrm{Zn}, \mathrm{Co}, \mathrm{Cr}, \mathrm{P}, \mathrm{Cu} \text { ) analizleri yapıldı. } \\
\text { Kimyasal rafinasyon sürecinde renk (Lovibond tintometer), serbest yağ asitliği ve peroksit değerleri } \\
\text { sırasıyla } 2.7-16, \% 0.09-2.12,1.08-10.95 \mathrm{mEqO} / \mathrm{kg} \text { aralığında değişim gösterdi. Oleik, linoleik ve linolenik } \\
\text { asit içerikleri kimyasal rafinasyon aşamalarında sırasıla \%30.580-30.486, \%54.703-54.164 ve \%0.993- } \\
0.972 \text { aralığında değişti. Ham mısır yağında ve gum giderme-nötralizasyon aşamasından sonra trans yağ } \\
\text { asidi belirlenemez iken, ağartılmış mısır yağında çok düşük miktarlarda trans oleik asit (\%0.040) ve toplam } \\
\text { trans linoleik asit (\%0.132) tespit edildi. Toplam trans yağ asidi içeriği kimyasal rafinasyonun son } \\
\text { aşamasında bir miktar artış gösterdi. Bununla birlikte, toplam trans yağ asidi içeriği \%3'ün altında kald. } \\
\text { Kimyasal rafinasyon işlemi sonunda Na, Mg, K, P, Ca, Mn, Fe, Pb, Ni, Cr, Cu element içeriklerinin çok } \\
\text { önemli düzeyde azaldığ1 açık bir şekilde görüldü. Cd, Co ve Zn elementleri ham mısır yağında tespit } \\
\text { edilmesine rağmen ise rafine mısır yağında bu elementler tespit edilemedi. Elde edilen sonuçlar kimyasal } \\
\text { rafinasyonu prosesinin mısır yağının bazı kalite özelliklerine ve bilhassa element içeriklerine etkili } \\
\text { olduğunu gösterdi. }\end{array}$ \\
\hline
\end{tabular}




\section{Introduction}

Edible oil is a required ingredient in human nutrition and in the production of certain foods. Edible oil technology is one of the leading sectors of today's food industry, whose production process starts from the field and continues in modern enterprises and goes to the houses where consumption occurs (Kuleaşan, 2004).

Edible oils are the most concentrated source of energy, they have a carrier function for fat-soluble vitamins, make food more delicious and contribute to the feeling of fullness after meals. In addition, edible oils are of great importance in human nutrition in terms of fatty acids that cannot be synthesized by the body (Nas et al., 2001). The chemical structure, metabolism, amount and quality parameters of oils consumed daily have a critical effect on health (Kostik et al., 2013).

Corn (Zea mays L.) is a member of the Maydeae tribe Gramineae grass family (Lara and Saldivar, 2019). Corn is the most important cereal grain in terms of production today, has high value and economic importance worldwide (Lara and Saldivar, 2019; Food and Agriculture Organization, 2018). The majority of commercially produced corn oil is extracted from the seed (Arellano et al., 2019). Corn oil exhibits excellent oxidative stability in many uses, such as when used as a frying oil. Corn oil contains high levels of unsaturated fatty acids, the main components of which are linoleic and oleic acids. As with other vegetable oils, the fatty acid composition of corn oil depends on factors such as climatic conditions, growing season and genotype. Refined corn oil; besides being used as salad oil and frying oil, it is used to obtain technical oils as raw materials in various lipid modification processes. It has an important place among vegetable oils due to its usefulness in a variety of food uses and has excellent sensory and nutritional properties (Arellano et al., 2019; O'Brien, 2008). High quality refined corn oil can be obtained by refining free fatty acids and phospholipids from crude oil.

Undesirable components such as free fatty acids (FFAs), phospholipids and pigments can negatively affect oil quality in terms of taste, appearance, physicochemical properties, and oxidative stability (Jiang et al., 2015, Zhu et al., 2015). Vegetable oils must be refined in order to be consumed. In general terms, refining vegetable oils refers to the separation of triglycerides from oil-insoluble impurities. The purpose of refining is to produce partially refined oils for hydrogenation or fully refined oils with good taste, odor, appearance properties and shelf life with high efficiency and low cost. Substances other than triglycerides in crude oil differ in amount and variety according to the conditions of cultivation and storage, as well as the processes applied to seed and crude oil. The refining processes should be directed towards obtaining a high and permanent quality end product from raw materials of different properties. In order to achieve this purpose or in other words, to obtain an acceptable product with refining methods, the crude oil should contain low levels of non-triglycerides (Taşan et al., 2011). Chemical refining includes degumming, neutralization, bleaching, winterization and deodorization processes (Taşan, 1999).
Whether edible oils are of consumable quality can also be evaluated by determining some trace metals. The body needs some metals in trace amounts. However, it is stated that high amounts of heavy metals have carcinogenic, mutagenic, teratogenic and endocrine disrupting effects, while others may cause neurological and behavioral changes. In addition, freely available heavy metals can break the molecular bonds and increase the production of free radicals, thereby causing oxidative stress (Angioni et al., 2006; Ali et al., 2013). Oxidative stress disrupts the antioxidant defense system of cells and can lead to cell damage and cell death (Mudipalli, 2008; Das et al., 2008).

The aim of this study is, during the refining of crude corn oil by chemical refining technique; to determine and compare some physical and chemical properties, oxidative stability values, geometric isomerization that may occur in fatty acids at some stages of refining applications and changes that can be seen in 14 different element contents.

\section{Material and Method}

\section{Material}

The research material was taken from the refining unit of private refining company located in the province of Edirne, which applies chemically refining technique to crude corn oil. This refining company, which applies the refining process to crude corn oils, imports raw corn oils from abroad.

In the study, corn oil samples were taken from the crude corn oil, which entered the chemical refining unit, and the combined degumming-neutralization, bleaching, winterization and deodorization stages of the chemical refining unit respectively.

The sampling process was carried out in three different production periods with an interval of 10 days; during these production periods, the same crude corn oil was used and the same refining parameters (temperature, pressure, addition of alkali, use of bleaching earth, processing times etc.) were applied.

During the combined degumming-neutralization stage, heating up to $90^{\circ} \mathrm{C}$ was applied, in addition, $1 \mathrm{~L} 85 \%$ phosphoric acid for per $1000 \mathrm{~kg}$ and $7 \mathrm{~L}$ sodium hydroxide solutions for per $1000 \mathrm{~kg}$ added; in the bleaching stage, heating up to $100^{\circ} \mathrm{C}$, addition of $12 \mathrm{~kg}$ synthetic silica bleaching earth for per $1000 \mathrm{~kg}$ and $750 \mathrm{~mm} \mathrm{Hg}$ vacuum applied; $2 \mathrm{~kg}$ perlite for per $1000 \mathrm{~kg}$ was added in the winterization; in the deodorization stage, heating was applied to $150-170^{\circ} \mathrm{C}$.

The samples taken were filled in $1 \mathrm{~L}$ brown glass bottles with no overhead gap to protect against oxidation. Analyzes in which element contents were determined were carried out in laboratories within Tekirdağ Namık Kemal University Scientific and Technological Research Application and Research Center (NABILTEM) and Yildiz Technical University Science and Technology Application and Research Center. A significant part of the analysis was done immediately without wasting time in the vegetable oil factory where samples were obtained and refining was applied. 


\section{Method}

Determination of Color Value

The color values of the samples were determined with the Lovibond tintometer PFXi-880 and a $5 \frac{1}{4}$ " cuvette was used for measuring operations (Anonymous, 1990).

Determination of \% Free Fatty Acidity Value

The free fatty acid value is stated as the percentage of oleic acid in the total free fatty acids according to the IUPAC 2.201 (Anonymous, 1987) method.

\section{Determination of Peroxide Value}

Peroxide value; it is a measure of the amount of active oxygen in oils, the amount of peroxide oxygen in $1 \mathrm{~kg}$ of oil, in milliequvalantgrams. IUPAC 2.501 (Anonymous, 1987) method was used to determine the peroxide value of the samples examined.

\section{Determination of Fatty Acid Composition}

The oil samples examined were converted to fatty acid methyl esters by $\mathrm{BF}_{3}$-methanol according to AOCS Ce 2-66 method (AOCS, 1992). Chromatograms showing fatty acid compositions were obtained by injecting $0.5 \mu \mathrm{l}$ of fatty acid methyl esters into the gas chromatography (GC). Agilent 6890 $\mathrm{N}$ model gas chromatography (Agilent, USA) (Anonymous, 2002), flame ionization detector (FID) and HP-88 (Coated with $88 \%$ cyanopropylmethyl-aryl polysiloxane, silica capillary column, $100 \mathrm{~m} \times 250 \mu \mathrm{m}$ i.d., $0.20 \mu \mathrm{m}$ film) column were used. Carrier gas helium, carrier gas flow $1 \mathrm{ml} / \mathrm{min}$. The peaks of GC chromatograms were tentatively identified by comparing the retention times and area percentages with those of authentic standards of fatty acid methyl esters obtained from $\mathrm{Nu}-\mathrm{Chek}-P r e p$ Inc. (Elysian, MN). Methyl esters of trans-9-elaidic and cis-trans isomers of linoleic acid were purchased from Supleco Inc. (USA). Samples were separately analyzed in triplicate. The final results were expressed as relative percentage of individual fatty acid.

Determination of Element Contents with Inductively Coupled Plasma / Optical Emission Spectroscopy (ICPOES) and Inductively Coupled Plasma / Mass Spectroscopy (ICP-MS)

In order to eliminate the organic compounds in the oil samples and to transfer the inorganic compounds to the soluble phase, the solubilization processes were carried out using the closed system wet burning method. For this purpose, the NovaWAVE model automated microwave digestion system was used. All samples and standards were used by diluting with ultra-pure water.

The concentration of $\mathrm{Na}, \mathrm{Mg}, \mathrm{K}, \mathrm{Ca}, \mathrm{P}$ elements was determined with the Inductively Coupled Plasma / Optical Emission Spectroscopy (ICP-OES) device equipped with the SPECTROBLUE model Smart Analyzer Vision software. The concentration of $\mathrm{Fe}, \mathrm{Pb}, \mathrm{Cd}, \mathrm{Ni}, \mathrm{Mn}, \mathrm{Zn}, \mathrm{Co}$, $\mathrm{Cr}$, and $\mathrm{Cu}$ elements was determined with the Agilent 7700 model Inductively Coupled Plasma / Mass Spectroscopy (ICP-MS) device.

In the process, $0.5 \mathrm{~g}$ of samples were weighed. Samples were placed in microwave tubes and $9 \mathrm{ml}$ of $\mathrm{HNO}_{3}$ and 3 $\mathrm{ml}$ of $\mathrm{H}_{2} \mathrm{O}_{2}$ were added. The lids of the microwave containers were closed and placed in the microwave oven, burning was performed in the appropriate program. In the first 15 minutes, a temperature of $145^{\circ} \mathrm{C}$ was reached gradually. It was held under these conditions for 5 minutes. After this stage, the temperature reached $175^{\circ} \mathrm{C}$ in 5.5 minutes. In these conditions, gradual combustion took place by keeping it in 4.5 minutes. After burning, the caps of the cooled tubes were opened in the fume hood, the lid and the walls of the container were rinse well. Some ultrapure water was added to the samples and filtered using filter papers. After dissolution, the filtrate was taken and completed to $25 \mathrm{~mL}$ (NMKL, 2011).

Elemental analyzes of prepared samples were performed in Inductively Coupled Plasma / Optical Emission Spectroscopy (ICP-OES) and Inductively Coupled Plasma / Mass Spectroscopy (ICP-MS) devices. Standard solutions at the desired concentrations for $\mathrm{Na}$, $\mathrm{Mg}, \mathrm{K}, \mathrm{Ca}, \mathrm{Fe}, \mathrm{Pb}, \mathrm{Cd}, \mathrm{Ni}, \mathrm{Mn}, \mathrm{Zn}, \mathrm{Co}, \mathrm{Cr}, \mathrm{P}$ and $\mathrm{Cu}$ were prepared from CPI International's $1000 \mathrm{mg} / \mathrm{L}$ stock solutions. The same processes were applied in the blind sample. Three parallels were studied for each sample and the results are averaged.

\section{Statistical analysis}

Variance analysis was applied to the data obtained as a result of the study by using SPSS package program according to random trial pattern. Duncan multiple comparison test applied to important variation sources (Soysal, 1998).

\section{Results and Discussion}

\section{Color Values}

The average of Lovibond tintometer color values of corn oil samples taken from each of the process stages of the unit where chemically refining was applied in three different production periods were shown in Table 1. Yellow color did not change in corn oil samples; the red color appears to be an average of 16 units in crude corn oil and an average of 2.7 units at the end of refining. While the red color value of crude oil samples was 16.0 on average, this value decreased to 9.3 in the degumming-neutralization stage. Decrease in the bleaching and winterization stages to an average of 5.2 and 5.0 , respectively, continued. After the deodorization process, it decreased to an average of 2.7. As a result of variance analysis, these changes were found statistically significant at the level of $\mathrm{P}<0.01$. Xie et al. (2019); in their study, they determined the effect of chemically refining on the color value of soybean oil. Color value was determined as $4.30 \pm 0.20$ in crude oil; after neutralization, decolorization and deodorization, it was determined as $2.50 \pm 0.10,1.10 \pm 0.10$ and $0.20 \pm 0.00$, respectively. Chewa et al. (2016) determined the $L^{*}, a^{*}$ and $b^{*}$ color values of crude and chemically refined kenaf (hibiscus cannabinus) seed oil. $L^{*}, a^{*}$ and $b^{*}$ color values in crude oil were determined as $11.55 \pm 0.29$, $91.94 \pm 0.15$ and $14.50 \pm 0.54$, respectively. At the end of the chemical refining process, it was determined as $6.57 \pm 0.15$, $-2.14 \pm 0.07$ and $6.43 \pm 0.28$, respectively.

Table 1. Changes of quality indices in corn oil during chemical refining ${ }^{1}$

\begin{tabular}{l|ccccc}
\hline Quality indices & Crude & Degummed- Neutralized & Bleached & Winterized & Deodorized \\
\hline Color & $16.0 \pm 0.2^{\mathrm{a}}$ & $9.3 \pm 0.57^{\mathrm{b}}$ & $5.2 \pm 0.05^{\mathrm{c}}$ & $5.0 \pm 0.05^{\mathrm{c}}$ & $2.7 \pm 5.43^{\mathrm{d}}$ \\
FFA $(\%)$ & $2.12 \pm 0.08^{\mathrm{c}}$ & $0.13 \pm 0.01^{\mathrm{b}}$ & $0.11 \pm 0.01^{\mathrm{ab}}$ & $0.10 \pm 0.00^{\mathrm{a}}$ & $0.09 \pm 0.00^{\mathrm{a}}$ \\
$\mathrm{PV}(\mathrm{mEqO} / \mathrm{kg})$ & $10.95 \pm 0.11^{\mathrm{d}}$ & $12.54 \pm 0.12^{\mathrm{e}}$ & $3.89 \pm 0.50^{\mathrm{b}}$ & $6.76 \pm 0.20^{\mathrm{c}}$ & $1.08 \pm 0.03^{\mathrm{a}}$ \\
\hline
\end{tabular}

${ }^{1}$ Each value is an average of three determinations, the mean \pm standard deviation (SD). The means in each row with different letter (a-d) are significantly different $(\mathrm{P}<0.01$, Duncan's multiple range test $)$. FFA $=$ free fatty acid, $\mathrm{PV}=$ peroxide value. 
In the degumming-neutralization stage, which is the first stage of the refining processes, the red color value decreased significantly $(\mathrm{P}<0.01)$, and the color unfolded. Some researchers have reported that the lightening of the color was due to the reduction of the color substance and the reduction of acidity during the neutralization stage (Taşan, 1999). With the bleaching process, which aims to lighten the color using bleaching soil, the color value was reduced significantly $(\mathrm{P}<0.01)$. On the other hand, there was a statistically insignificant decrease in the winterization stage. According to the data obtained in our study, the lightening continued with deodorization process. It is reported that the reason for this might be that naturally occurring pigments in oil undergo chemical changes at high temperatures and become discolored. (Karaali 1981).

\section{\% Free Fatty Acidity Value}

The average of free fatty acidity values of corn oil samples taken from each of the process steps of the unit where chemical refining was applied in three different production periods were shown in Table 1. It can be seen that oil samples tend to decrease in free fatty acid values during chemical refining process stages. The free fatty acid value, which was $2.12 \%$ in crude corn oil, decreased to $0.09 \%$ by deodorization process at the end of the refining process.

While the free fatty acid value of crude oil samples averaged $2.12 \%$, this value increased to $0.13 \%$ in the degumming-neutralization stage. On the other hand, after bleaching, winterization and deodorization process stages, on average $0.11 \%$; it was determined as $0.10 \%$ and $0.09 \%$. As a result of variance analysis, these changes were found statistically significant at the level of $\mathrm{P}<0.01$. Drira et al. (2018) determined the effects of chemical refining steps on pomace olive oil, free fatty acid. The free fatty acid (\%) level of $6.90 \pm 0.10$ in crude oil is $4.74 \pm 0.07$ after the winterized stage; $0.20 \pm 0.00$ after the neutralization stage; $0.28 \pm 0.00$ after decolorization and $0.14 \pm 0.00$ after deodorization. Liu et al. (2019a) determined the free fatty acid (\%) content of crude coconut oil as 5.70 \pm 0.03 ; after degumming, neutralization, bleaching and deodorization proces stages, it decreased to $5.87 \pm 0.14,0.32 \pm 0.01$, $0.39 \pm 0.02$ and $0.12 \pm 0.01$ respectively.

The high rate of free fatty acids that can be found in oils adversely affects the taste and smell and durability of the oil, therefore, high amount of fatty acids in edible vegetable oils is considered as a factor that reduces quality. Free fatty acidity can occur during the ripening period of the seed, as well as mechanical damage, storage and transportation conditions in the seed, and processing conditions during extraction of crude oil can significantly affect the content of free fatty acid (Nas et al., 2001, Taşan and Demirci, 2003). As the free fatty acids are converted into soap solutions with the use of alkali in chemical refining, the most important reduction occurred in the combined degumming-neutralization phase $(\mathrm{P}<0.01)$, no significant change was observed after the combined degumming-neutralization phase. Effective factors in the neutralization phase; temperature, duration, concentration of the base solution used, the amount of free fatty acid content of the oil and other impurities (Taşan, 1999).

\section{Peroxide Value}

The average of peroxide values of corn oil samples taken from each of the process steps of the unit where chemical refining was applied in three different production periods were shown in Table 1. Peroxide value; it was determined as the highest degumming-neutralization stage and the lowest deodorization stage, on average 12.54 $\mathrm{mEqO}_{2} / \mathrm{kg}$ and $1.08 \mathrm{mEqO}_{2} / \mathrm{kg}$, respectively.

The peroxide value, which increased to 12.54 $\mathrm{mEqO}_{2} / \mathrm{kg}$ during the degumming-neutralization stage, decreased significantly during the bleaching phase and became $3.89 \mathrm{mEqO}_{2} / \mathrm{kg}$. The peroxide value, which reached $6.76 \mathrm{mEqO}_{2} / \mathrm{kg}$ again during the winterization stage, was determined as $1.08 \quad \mathrm{mEqO}_{2} / \mathrm{kg}$ after deodorization stage.

As a result of variance analysis, the differences between the processing stages of the chemical refining method were found to be statistically significant at the level of $\mathrm{P}<0.01$. Xie et al. (2019) determined the peroxide value of crude soybean oil to $3.50 \pm 0.18(\mathrm{mmol} / \mathrm{kg})$; this value was determined as $6.12 \pm 0.14, \quad 5.07 \pm 0.20$ and $0.81 \pm 0.07$ $(\mathrm{mmol} / \mathrm{kg})$ in neutralized oil, bleached oil and deodorized oil, respectively. Liu et al. (2019a) aimed to determine the effects of chemical refining on the quality of coconut oil, they determined the peroxide value of crude coconut oil as $6.02 \pm 0.22 \mathrm{meg} / \mathrm{kg}$. The peroxide value decreased at each stage of the refining process $(5.16 \pm 0.14,2.60 \pm 0.06$, $3.52 \pm 0.10$ and $0.55 \pm 0.10 \mathrm{meg} / \mathrm{kg}$, after degumming, neutralization and bleaching respectively), at the end this value was found to be $0.24 \pm 0.00 \mathrm{meg} / \mathrm{kg}$ in deodorized oil. Liu et al. (2019b) determined peroxide values in raw and refined rice bran oil. Peroxide values found $5.29 \pm 0.20$ $(\mathrm{mmol} / \mathrm{kg})$ in crude oil, $3.92 \pm 0.19(\mathrm{mmol} / \mathrm{kg})$ in degumming oil, $0.34 \pm 0.07(\mathrm{mmol} / \mathrm{kg})$ in neutralized oil, $0.59 \pm 0.27(\mathrm{mmol} / \mathrm{kg})$ in bleached oil and $0.65 \pm 0.13$ $(\mathrm{mmol} / \mathrm{kg})$ in deodorized oil. These results in the literature are in agreement with the results of our study.

It is normal to have very little oxidative deterioration in oily raw materials. Because these deterioration products can be removed by refining processes. Mechanical damage during harvesting, storage and transportation and pretreatments applied can cause oxidative deterioration reactions (Taşan, 1999).

In the increase at degumming-neutralization stage, where the peroxide number reaches the highest values, the possibility of oil contact with air and the processing time can be considered to be effective. Rate and type of bleaching soil in the bleaching stage, temperature, duration and vacuum, are effective factors in the decrease in peroxide value. The peroxide value was significantly removed in the deodorization stage of the chemical refining.

\section{Fatty Acid Compositions}

Fatty acid compositions of corn oil samples taken from each of the process stages of the unit where chemical refining was applied in three different production periods were shown in Table 2. Also mean values of fatty acid compositions, total saturated fatty acids, total monounsaturated fatty acids, total polyunsaturated fatty acids, total unsaturated fatty acids, total trans fatty acids, total polyunsaturated fatty acids to total saturated fatty acids are shown in Table 2. 
Table 2. Average values of fatty acid compositions in the process of refining steps $(\%)^{1}$

\begin{tabular}{|c|c|c|c|c|c|c|}
\hline \multicolumn{2}{|c|}{ Fatty acids (\%) } & Crude & Degummed- Neutralized & Bleached & Winterized & Deodorized \\
\hline Myristic acid & C14:0 & $0.026 \pm 0.00$ & $0.029 \pm 0.00$ & $0.029 \pm 0.00$ & $0.029 \pm 0.00$ & $0.028 \pm 0.00$ \\
\hline Palmitic acid & C16:0 & $10.580 \pm 0.05^{\mathrm{a}}$ & $11.114 \pm 0.00^{\mathrm{b}}$ & $11.095 \pm 0.00^{\mathrm{b}}$ & $11.253 \pm 0.04^{\mathrm{b}}$ & $11.147 \pm 0.03^{b}$ \\
\hline Palmitoleic acid & C16:1 & $0.090 \pm 0.00$ & $0.038 \pm 0.00$ & $0.041 \pm 0.00$ & $0.060 \pm 0.00$ & $0.057 \pm 0.00$ \\
\hline Stearic acid & C18:0 & $2.167 \pm 0.00^{\mathrm{a}}$ & $2.065 \pm 0.00^{\mathrm{b}}$ & $2.073 \pm 0.00^{\mathrm{b}}$ & $2.064 \pm 0.00^{\mathrm{b}}$ & $2.051 \pm 0.00^{\mathrm{b}}$ \\
\hline Elaidic acid & C18:1 trans $^{2}$ & $-\mathrm{a}$ & $-a$ & $0.040 \pm 0.00^{\mathrm{b}}$ & $0.039 \pm 0.00^{\mathrm{b}}$ & $0.039 \pm 0.00^{\mathrm{b}}$ \\
\hline Oleic acid & C18:1 & $30.580 \pm 0.03^{\mathrm{a}}$ & $30.472 \pm 0.00^{\mathrm{a}}$ & $30.461 \pm 0.00^{\mathrm{a}}$ & $30.492 \pm 0.02^{\mathrm{a}}$ & $30.486 \pm 0.00^{\mathrm{a}}$ \\
\hline Linoelaidic & $\Sigma \mathrm{C} 18: 2 \operatorname{trans}^{3}$ & $-a$ & $-\mathrm{a}$ & $0,132 \pm 0.00^{\mathrm{b}}$ & $0,131 \pm 0.00^{\mathrm{b}}$ & $0,175 \pm 0.00^{\mathrm{c}}$ \\
\hline Linoleic acid & C18:2 & $54.703 \pm 0.08^{\mathrm{a}}$ & $54.449 \pm 0.00^{\mathrm{ab}}$ & $54.243 \pm 0.01^{\mathrm{ab}}$ & $54.097 \pm 0.03^{b}$ & $54.164 \pm 0.04^{\mathrm{ab}}$ \\
\hline Linolenic acid & C18:3 & $0.993 \pm 0.00^{\mathrm{a}}$ & $0.970 \pm 0.00^{\mathrm{a}}$ & $0.970 \pm 0.00^{\mathrm{a}}$ & $0.968 \pm 0.00^{\mathrm{a}}$ & $0.972 \pm 0.00^{\mathrm{a}}$ \\
\hline Arachidic acid & $\mathrm{C} 20: 0$ & $0.505 \pm 0.00$ & $0.500 \pm 0.00$ & $0.546 \pm 0.00$ & $0.506 \pm 0.01$ & $0.513 \pm 0.01$ \\
\hline Eicosadienoic acid & $\mathrm{C} 20: 2$ & $0.050 \pm 0.00$ & $0.055 \pm 0.00$ & $0.058 \pm 0.00$ & $0.051 \pm 0.00$ & $0.052 \pm 0.00$ \\
\hline Gadoleic acid & C20:1 & $0.306 \pm 0.00$ & $0.308 \pm 0.00$ & $0.312 \pm 0.00$ & $0.310 \pm 0.00$ & $0.316 \pm 0.00$ \\
\hline \multicolumn{2}{|c|}{ Total Saturated Fatty Acids } & $13.278^{\mathrm{a}}$ & $13.708^{\mathrm{b}}$ & $13.743 b$ & $13.852^{\mathrm{b}}$ & $13.739^{\mathrm{b}}$ \\
\hline \multicolumn{2}{|c|}{ Total Monounsaturated Fatty Acids } & $30.976^{\mathrm{a}}$ & $30.818^{\mathrm{a}}$ & $30.854^{\mathrm{a}}$ & $30.901^{\mathrm{a}}$ & $30.898^{\mathrm{a}}$ \\
\hline \multicolumn{2}{|c|}{ Total Polyunsaturated Fatty Acids } & $55.746^{\mathrm{a}}$ & $55.474^{\mathrm{b}}$ & $55.403^{\mathrm{b}}$ & $55.247^{\mathrm{c}}$ & $55.363^{\mathrm{bc}}$ \\
\hline \multirow{2}{*}{\multicolumn{2}{|c|}{$\begin{array}{l}\text { Total Unsaturated Fatty Acids } \\
\text { Total Unsaturated / Total Saturated }\end{array}$}} & $86.722^{a}$ & $86.292^{\mathrm{ab}}$ & $86.257^{\mathrm{ab}}$ & $86.148^{b}$ & $86.261^{\mathrm{ab}}$ \\
\hline & & 6.531 & 6.295 & 6.276 & 6.219 & 6.278 \\
\hline \multicolumn{2}{|c|}{ Total Trans Fatty Acids } & $-\mathrm{a}$ & $-a$ & $0.172^{\mathrm{b}}$ & $0.170^{\mathrm{b}}$ & $0.214^{\mathrm{c}}$ \\
\hline
\end{tabular}

${ }^{1}$ Each value is an average of three determinations, the mean \pm standard deviation (SD), and are expressed as a weight percentage of total FA methyl esters. The means in each row with different letter (a-c) are significantly different $\left(\mathrm{P}<0.01\right.$, Duncan's multiple range test). ${ }^{2} \mathrm{Constituted}$ of $\mathrm{C} 18: 1 \Delta 9$ trans, ${ }^{3}$ Sum of only $\Delta 9$ cis, $\Delta 12$ trans and $\Delta 9$ trans, $\Delta 12$ cis isomers for the $\mathrm{C} 18: 2$.

A total of 12 types of fatty acids were determined in the corn oil samples taken from the refining unit during three different production periods. In some corn oil samples, elaidic acid (trans oleic acid) and linoelaidic acid (total trans linoleic acid) formations were also encountered. According to the data obtained in the study, the most common fatty acids in corn oil samples were palmitic (C16:0), oleic (C18:1) and linoleic (C18:2) acids. Next comes stearic acid (C18:0) in proportions exceeding $2 \%$ and linolenic $(\mathrm{C} 18: 3)$ acid in a ratio that approximates $1 \%$. Other fatty acids, myristic (C14:0), palmitoleic (C16:1), arachidic (C20:0), eicosadienoic (C20:2), gadoleic (C20:1), were well below $1 \%$.

When Table 2 is examined, it is seen that 4 types of saturated fatty acid were detected in corn oil samples taken and examined in three different production periods; C14:0, C16:0, C18:0 and C20:0. While total saturated fatty acid was $13.278 \%$ in crude corn oil, it was determined as $13.739 \%$ as a result of refining although the total saturated fatty acids showed some fluctuation during the chemically refining process, it was found that only the degummingneutralization stage was effective and this difference was statistically significant at the level of $\mathrm{P}<0.01$. It can be seen that the ratio of $\mathrm{C} 16: 0$ was between $10.580-11.253$ on average, reaching an average of $11.114 \%$ with the degumming-neutralization process and an average of $11.253 \%$ during the winterization stage. The highest mean value for C18:0 was determined in crude corn oil $(2.167 \%)$ and the lowest mean value was determined in deodorized corn oil $(2.051 \%)$. As a result of variance analysis, it was observed that the differences occurred for C16:0 and C18:0 were statistically significant $(\mathrm{P}<0.01)$. For both saturated fatty acids C16:0 and C18:0, degumming-neutralization, bleaching, winterization and deodorization output were determined to be statistically identical with each other.

The process of winterization in refining can generally reduce the amount of high-melting saturated fatty acids such as palmitic and stearic acids (Taşan and Demirci, 2003). In the studies of Karaali (1981) and Taşan and Demirci (2003), the refinement of sunflower oil has determined decreases in palmitic and stearic acid ratios. In our study, as explained in the statistical evaluation, statistically significant changes were observed after applying degumming-neutralization process to crude corn oil, and the next steps did not have any effect. Liu et al. (2019a) determined the fatty acid composition of coconut oil treated by chemical refining. The amount of highest rates fatty acids C12:0, C14:0 and C16:0 and total amount of saturated fatty acids in crude oil changed from $38.11 \pm 0.13, \quad 19.43 \pm 0.46, \quad 13.17 \pm 0.27, \quad 82.72 \pm 0.19$ to $40.31 \pm 0.13,19.54 \pm 0.28,12.50 \pm 0.08,85.41 \pm 0.36$ at the end of deodorization. It may also be due to the different processing parameters used in the refining methods applied in the differences observed in these studies.

Three kinds of monounsaturated fatty acids, C16:1, C18:1 and C20:1 are determined in corn oil samples taken and examined in three different production periods. While the ratio of total unsaturated fatty acids was $30.976 \%$ in crude corn oil, it was determined as $30.889 \%$ as a result of refining process. As a result of variance analysis, the differences occurred during the refining process were found to be statistically insignificant $(\mathrm{P}>0.01)$. On the other hand, three types of polyunsaturated fatty acids, C18:2, C18:3 and C20:2, have been determined, and an average of $55.746 \%$ in crude corn oil and $55.363 \%$ at the end of refining process. The average value of total unsaturated fatty acids, consisting of total mono and polyunsaturated fatty acids, was determined as $86.722 \%$ in crude corn oil, and the average of deodorization output at the end of refining was $86.261 \%$. In addition, while the total unsaturated / total saturated fatty acids ratio was $6.531 \%$ in crude corn oil, this value decreased to $6.278 \%$ as a result of deodorization process. Liu et al. (2019b) investigated the effects of refining process on rice bran oil. They determined saturated fatty acid, monounsaturated fatty acid and polyunsaturated fatty acid amounts ranged from $19.28 \pm 0.03$ to $19.55 \pm 0.01$ from $39.67 \pm 0.07$ to $40.31 \pm 0.06$ and from $39.61 \pm 0.02$ to $35.41 \pm 0.06$ in crude and deodorized oil, respectively. 
In the chemically refining processes, C18:1 fatty acid average between $30.461-30.580 \%, \mathrm{C} 18: 2$ fatty acid average between $54.097-54.703 \%$ and $\mathrm{C} 18: 3$ fatty acid average between $0.968-0.993 \%$ was determined.

Some changes can be seen in monounsaturated and polyunsaturated fatty acids as a result of treatment with water, alkali-acid, bleaching earth used during refining processes, high temperatures, oxidative events caused by air contact, changes that can be seen in saturated fatty acids during winterization stages, effects such as geometric isomerization phenomenon (Taşan, 1999). Çalışkan (2008) states that unsaturated fatty acids (oleic, linoleic) in corn oil were not affected by refining processes, only a decrease in linolenic acid values during deodorization. In our study, some reduction in linolenic acid was determined. Similarly, there was a decrease in the oleic acid ratio in the refining process. However, these changes are not statistically significant as a result of statistical evaluations. Chewa et al. (2016) identified C18:1, followed by C18:2 and $\mathrm{C} 16: 0$, as the most common fatty acid in crude and refined kenaf seed oils. After refining processes, they identified a significant decrease in saturated fatty acids and a significant increase in total monounsaturated fatty acids. Xie et al. (2019) determined the fatty acid composition of soybean oil, which was chemically refined. The most common fatty acids found in crude soybean oil are C18:2, followed by $\mathrm{C} 18: 1$ and $\mathrm{C} 16: 0$. While these three fatty acid $(\%)$ in crude oil were $54.06 \pm 0.08,22.69 \pm 0.01$ and $10.6 \pm 0.02$, respectively, they were determined after deodorization at $54.60 \pm 0.09,22.41 \pm 0.0$ and $10.89 \pm 0.04$, respectively. Karayiğit (2018) determined total saturated fatty acid value of sunflower oil applied chemical refining was $10.24 \pm 0.003 \%$ in crude oil and $10.01 \pm 0.003 \%$ in deodorized oil; total polyunsaturated fatty acid value was determined as $64.50 \pm 0.003$ in crude oil and $64.88 \pm 0.005$ in deodorized oil. In light of the evaluations in the literature, it shows that there is very little difference between the rates of mono and polyunsaturated fatty acids of crude oils and refined oils.

An average of $0.040 \%$ elaidic acid (trans oleic acid, C18:1t) was determined in bleached corn oil samples taken and analyzed in three different production periods. There was no increase in elaidic acid in corn oil samples, which came out of the deodorization stage, and was found to be $0.039 \%$ on average. In our study, trans fatty acid was not determined in crude corn oil samples. Also, linoelaidic acid (trans linoleic acid, $0.132 \%$ ) was detected in bleached corn oil. By increasing this value, linoelaidic acid was detected in the deodorized corn oil as $0.175 \%$. After the bleaching stage, the total trans fatty acid content little more increased in the last stage of the chemically refining. However, total trans fatty acid content of refined corn oil was $<0.3 \%$.

Due to the high temperatures and durations applied at the stages of obtaining crude oil from oilseeds, trans fatty acid formations can be encountered even in vegetable crude oils. The differences in the fatty acid composition of the deodorized oil with different operating parameters used in the deodorization stage can lead to the formation of trans fatty acids at different rates and types (Taşan and Demirci, 2003; Taşan et al., 2011). Xie et al. (2019); determined the change in trans fatty acid (\%) level of chemically refined soybean oil. Total trans fatty acid level was determined as $0.11 \pm 0.01$ in crude oil, this value was $0.11 \pm 0.04$ after neutralization; it was determined as $0.14 \pm 0.02$ after the decolorizing stage and $1.08 \pm 0.07$ after the deodorization stage. In various studies, it was stated that geometric isomeration occured depending on the high temperature and long time parameters used at deodorization stage (Taşan and Demirci, 2003).

\section{Element Contents}

The average of the element content values of corn oil samples taken from chemical refining stages are shown in Table 3. Corn oil samples taken from the refining unit in three different production periods were analyzed for 14 elements in total, and changes in the refining stages were determined. Identified elements were sodium (Na), magnesium $(\mathrm{Mg})$, potassium $(\mathrm{K})$, phosphorus $(\mathrm{P})$, calcium $(\mathrm{Ca})$, manganese $(\mathrm{Mn})$, iron $(\mathrm{Fe})$, lead $(\mathrm{Pb})$, cadmium $(\mathrm{Cd})$, nickel $(\mathrm{Ni})$, zinc $(\mathrm{Zn})$, cobalt $(\mathrm{Co})$, chromium $(\mathrm{Cr})$ and copper $(\mathrm{Cu})$ elements. Duncan multiple comparison test was performed on the major variation sources, and the groups are shown in Table 3.

Table 3. Average values of element contents in the process of refining steps ( $\mathrm{ppm})^{1}$

\begin{tabular}{|c|c|c|c|c|c|}
\hline Elements & Crude & Degummed- Neutralized & Bleached & Winterized & Deodorized \\
\hline $\mathrm{Na}$ & $38.00 \pm 0.35^{\mathrm{a}}$ & $10.01 \pm 0.16^{\mathrm{b}}$ & $9.52 \pm 0.45^{\mathrm{b}}$ & $8.80 \pm 0.48^{b}$ & $8.97 \pm 0.79^{b}$ \\
\hline $\mathrm{Mg}$ & $21.14 \pm 0.09^{\mathrm{a}}$ & $1.14 \pm 0.02^{\mathrm{b}}$ & $0.28 \pm 0.01^{\mathrm{c}}$ & $0.92 \pm 0.00^{\mathrm{b}}$ & $1.38 \pm 0.01^{\mathrm{b}}$ \\
\hline $\mathrm{K}^{\circ}$ & $11.74 \pm 1.07^{\mathrm{a}}$ & $1.12 \pm 0.38^{\mathrm{c}}$ & $7.55 \pm 1.05^{\mathrm{b}}$ & $11.02 \pm 0.65^{\mathrm{a}}$ & $9.78 \pm 0.16^{\mathrm{ab}}$ \\
\hline $\mathrm{P}$ & $107.13 \pm 0.31^{\mathrm{a}}$ & $1.14 \pm 0.10^{\mathrm{b}}$ & $0.97 \pm 0.12^{\mathrm{b}}$ & $1.06 \pm 0.15^{\mathrm{b}}$ & $0.264 \pm 0.05^{\mathrm{c}}$ \\
\hline $\mathrm{Ca}$ & $108.21 \pm 0.79^{a}$ & $31.29 \pm 0.33^{c}$ & $36.83 \pm 0.56^{\mathrm{c}}$ & $54.97 \pm 0.29^{\mathrm{b}}$ & $8.27 \pm 0.32^{\mathrm{d}}$ \\
\hline $\mathrm{Mn}$ & $0.096 \pm 0.00^{\mathrm{a}}$ & $0.107 \pm 0.00^{\mathrm{a}}$ & $0.045 \pm 0.00^{\mathrm{b}}$ & $0.018 \pm 0.00^{c}$ & $0.018 \pm 0.00^{\mathrm{c}}$ \\
\hline $\mathrm{Fe}$ & $4.65 \pm 0.02^{\mathrm{a}}$ & $3.29 \pm 0.22^{b}$ & $1.48 \pm 0.02^{\mathrm{c}}$ & $0.75 \pm 0.01^{\mathrm{d}}$ & $0.54 \pm 0.01^{\mathrm{e}}$ \\
\hline $\mathrm{Pb}$ & $0.227 \pm 0.01^{\mathrm{a}}$ & $0.183 \pm 0.00^{\mathrm{b}}$ & $0.148 \pm 0.00^{\mathrm{bc}}$ & $0.123 \pm 0.00^{\mathrm{c}}$ & $0.089 \pm 0.00^{\circ}$ \\
\hline $\mathrm{Cd}$ & $0.057 \pm 0.00^{\mathrm{a}}$ & $0.004 \pm 0.00^{\mathrm{b}}$ & $\mathrm{ND}^{2}$ & ND & ND \\
\hline $\mathrm{Ni}$ & $0.899 \pm 0.01^{\mathrm{a}}$ & $0.482 \pm 0.01^{\mathrm{b}}$ & $0.284 \pm 0.02^{\mathrm{c}}$ & $0.319 \pm 0.01^{\mathrm{c}}$ & $0.102 \pm 0.00^{\mathrm{d}}$ \\
\hline $\mathrm{Zn}$ & $1.97 \pm 0.03^{\mathrm{a}}$ & $0.17 \pm 0.02^{\mathrm{b}}$ & ND & ND & ND \\
\hline Co & $0.047 \pm 0.00^{\mathrm{a}}$ & $0.029 \pm 0.00^{\mathrm{b}}$ & $0.014 \pm 0.00^{\mathrm{c}}$ & ND & ND \\
\hline $\mathrm{Cr}$ & $1.42 \pm 0.02^{\mathrm{a}}$ & $0.071 \pm 0.01^{\mathrm{c}}$ & $0.149 \pm 0.00^{\mathrm{b}}$ & $0.204 \pm 0.01^{\mathrm{b}}$ & $0.079 \pm 0.00^{\mathrm{c}}$ \\
\hline $\mathrm{Cu}$ & $0.148 \pm 0.00^{\mathrm{a}}$ & $0.053 \pm 0.00^{\mathrm{d}}$ & $0.063 \pm 0.00^{\mathrm{cd}}$ & $0.086 \pm 0.00^{\mathrm{b}}$ & $0.078 \pm 0.00^{\mathrm{bc}}$ \\
\hline
\end{tabular}

${ }^{\mathrm{1}}$ Each value is an average of three determinations, the mean \pm standard deviation (SD), The means in each row with different letter (a-d) are significantly different ( $\mathrm{P}<0.01$, Duncan's multiple range test). Element LOD (ppb) = Na:20.65; Mg:8.316; K:50; Ca:40; Fe:1.056; Pb:17; Cd:0.7297; Ni:4.098; Mn:0.5189 ; Zn:1.566; Co:2.713; Cr:2.517; P:10; Cu:2.009. ${ }^{2} \mathrm{ND}$ : Not Detected. 
Na element value, which was 38 ppm in crude corn oil, decreased to $8.97 \mathrm{ppm}$ in refined oil on the other hand, the $\mathrm{Mg}$ element value decreased to $1.38 \mathrm{ppm}$. As a result of variance analysis, the differences formed by refining were found to be statistically significant $(\mathrm{P}<0.01)$. The highest decrease in the $\mathrm{Na}$ element content was determined after the degumming-neutralization process, while the $\mathrm{Mg}$ element value decreased with the degummingneutralization and bleaching processes, it increased as a result of winterization and deodorization processes. Taşan and İmer (2018) determined $\mathrm{Na}$ content of cold pressed sunflower, hazelnut, flaxseed and sesame oil as $4.45 \pm 0.32$, $7.93 \pm 1.41,9.73 \pm 1.18$ and $8.69 \pm 1.92 \mathrm{ppm}$ respectively, and determined $\mathrm{Mg}$ content as $10.16 \pm 1.95,11.93 \pm 1.47$, $5.49 \pm 0.75$ and $15.18 \pm 2.91$ respectively. Karayiğit (2018) was determined $\mathrm{Na}$ amount in crude sunflower oil as $271.61 \mathrm{ppm}$ and 0 ppm in deodorized oil. Yüksel (2010) determined the content of $\mathrm{Mg}$ element in refined corn oil samples in the range of 0.003-0.027 ppm and 0.157-0.372 ppm in some sunflower oil and vegetable oil mixtures. The element contents in oilseeds and oily fruits may differ significantly depending on the distribution of elements in the soil, environmental and climatic conditions, variety characteristics and processing conditions (Tuna, 2011).

While the $\mathrm{K}$ and $\mathrm{Ca}$ element value in crude corn oil was $11.74 \mathrm{ppm}$ and $108.09 \mathrm{ppm}$, respectively, it was observed that these values decreased with degumming-neutralization process and increased with bleaching and winterization processes. As a result of the refining process, the $\mathrm{K}$ and $\mathrm{Ca}$ element value decreased to an average of $9.78 \mathrm{ppm}$ and $8.27 \mathrm{ppm}$, respectively. As a result of analysis of variance, the differences formed by refining were found to be statistically significant $(\mathrm{P}<0.01)$. Yüksel (2010) while determining the $\mathrm{Ca}$ element values in the refined corn oil between 0.053-0.111 ppm, was significantly lower than the values we find. Taşan and İmer (2018) determined the content $\mathrm{K}$ element in cold pressed sunflower, hazelnut, flaxseed and sesame oil as $7.10 \pm 1.43,9.69 \pm 1.39$, $4.40 \pm 0.49$ and $16.26 \pm 3.79 \mathrm{ppm}$, respectively and determined the content of the element $\mathrm{Ca}$ in the same cold press oils as 54.16 $\pm 5.52,52.65 \pm 8.56,24.58 \pm 1.57$ and $39.02 \pm 4.68$ ppm, respectively. Karayiğit (2018) determined the $\mathrm{K}$ and $\mathrm{Ca}$ amounts in crude sunflower oil as $1.55 \mathrm{ppm}$ and $2.73 \mathrm{ppm}$ and the $\mathrm{K}$ and $\mathrm{Ca}$ amounts in deodorized sunflower oil as $0 \mathrm{ppm}$.

On the other hand, $\mathrm{P}$ element value has been determined as $0.264 \mathrm{ppm}$ in refined corn oil by continuously decreasing with refining steps from 107.13 ppm at the beginning of the refining process. As a result of analysis of variance, the differences formed by refining were found to be statistically significant $(\mathrm{P}<0.01)$. Güler (2009) states that the phosphorus contained in vegetable oils was caused by phospholipids and its amount depends on the type of oilseed, soil and climatic conditions. The degumming-neutralization stage to the $\mathrm{P}$ element content was the most important stage and the $\mathrm{P}$ content has also decreased due to the phospholipids removed. Various researchers report that the $\mathrm{P}$ element content must be reduced before deodorization process (Taşan, 1999). Taşan and İmer (2018) determined the content of P element in cold pressed sunflower, hazelnut, flaxseed and sesame oil as $22.39 \pm 4.41,36.49 \pm 3.08,17.43 \pm 2.35$ and $50.10 \pm 10.78$ ppm respectively. Karayiğit (2018) determined the amount of $\mathrm{P}$ in crude and deodorized sunflower oil as $967.39 \mathrm{ppm}$ and $217.69 \mathrm{ppm}$. It is understood that the $\mathrm{P}$ value obtained in our study is quite reasonable compared to the values given in the literature.

Fe and Mn element values, which were $4.65 \mathrm{ppm}$ and $0.096 \mathrm{ppm}$ at the beginning, decreased to an average of $0.54 \mathrm{ppm}$ and $0.018 \mathrm{ppm}$ at the end of the refining. As a result of analysis of variance, the differences formed by refining were found to be statistically significant $(\mathrm{P}<0.01)$. Karayiğit (2018) determined the amount of $\mathrm{Mn}$ and Fe in crude and deodorized sunflower oil as $0.10 \mathrm{ppm}, 25.65$ ppm and 0.04 ppm, respectively. According to the results of our study, the Fe value found in crude corn oil decreased by $88.4 \%$. Bakırcıoğlu et al. (2013) Fe values determined by using different analysis methods in refined corn oil vary between 0.730-8.390 ppm. Yüksel (2010) determined Fe values in the range of $0.211-0.435 \mathrm{ppm}$ in refined corn oils, and the findings are close to our results. Kabaran (2015); determined that $\mathrm{Fe}$ content in olive oil samples produced in the Güzelyurt region is $875.06 \pm 806.85 \mathrm{ng} / \mathrm{ml}$ on average. $\mathrm{Fe}$ acts as a catalyst in the oxidation of oils due to its prooxidant property. For this reason, it is inconvenient to have very high levels in fats and it must be removed from the oil by refining (Güler, 2009).

$\mathrm{Pb}$ and $\mathrm{Cd}$ element values were determined as 0.222 ppm and 0.057 ppm in crude corn oil samples. The $\mathrm{Pb}$ element value showed continuous decreases in refining processes and decreased to an average of $0.089 \mathrm{ppm}$ at the end of refining, while the Cd element was not detected after the degumming-neutralization phase. As a result of variance analysis, the differences formed by refining were found significant $(\mathrm{P}<0.01)$. These results in crude corn oil may be a strong sign that there is a contamination in the food chain that starts from the soil and reaches the human. Cd element can also be found in crude corn oil for reasons such as being in agricultural areas, mixing with industrial processes or contaminating with phosphorus fertilizers. Bakırcıoğlu et al. (2013) determined the Pd value in refined corn oil in the range of 0.034-1.356 ppm, while determined the $\mathrm{Cd}$ amount in corn oil samples as $0.017 \pm 0.002 \mathrm{mg} / \mathrm{kg}$. Küçükkolbaşı et al. (2014) identified $\mathrm{Pb}$ element in crude corn oil as $1.9 \mathrm{ppm}$ and in refined corn oil as $0.04 \mathrm{ppm}$, while it was decreased by approximately $97.80 \%$. They determined the Cd element as $1.1 \mathrm{ppm}$ in crude corn oil and $0.0006 \mathrm{ppm}$ in deoderized corn oil with $99.90 \%$ reduction. In our study, the $\mathrm{Cd}$ was found in the crude corn oil at a lower rate, while the result of the bleaching process was completely disappeared. Taşan and İmer (2018) determined the content of $\mathrm{Pb}$ element in cold pressed sunflower as $0.58 \mathrm{ppm}$. In our study, the rate of reduction caused by refining was approximately $62.8 \%$.

Similarly, the Zn element was determined only in crude corn oil samples and samples taken after degummingneutralization process. The result of statistical evaluation is the same as Cd element. Küçükkolbaşı et al. (2014) detected $0.05 \mathrm{ppm} \mathrm{Zn}$ element with $4.7 \mathrm{ppm}$ in crude corn oil and $98.94 \%$ reduction in deodorized corn oil after refining. As a result, the differences arising from the refining process were statistically significant $(\mathrm{P}<0.01)$. Taşan and İmer (2018); determined the content of $\mathrm{Zn}$ element in cold pressed sunflower, hazelnut, flaxseed and sesame oil as $0.58 \pm 0.10,0.32 \pm 0.07,0.39 \pm 0.06$ and $0.24 \pm 0.07$ ppm respectively. 
While the Ni element value in crude oil was $0.899 \mathrm{ppm}$ on average, it decreased to $0.102 \mathrm{ppm}$ by refining. $\mathrm{Cr}$ decreased with degumming-neutralization and deodorization processes, but increased by bleaching and wintering processes. As a result of analysis of variance, while the differences formed by refining were found significant $(\mathrm{P}<0.01)$. Martinez et al. (2011) could not determine the Ni element in refined corn, soy, sunflower and olive oil. Bakırcıoğlu et al. (2013) reported three different results for their $\mathrm{Ni}$ element value in refined corn oil using three different methods: 0.034 ppm, 0.924 ppm and $1.356 \mathrm{ppm}$. They determined the value of $\mathrm{Cr}$ element in refined corn oil in the range of $0-0.546 \mathrm{ppm}$. It approaches the value of $0.079 \mathrm{ppm}$ we find. Karayiğit (2018) while determining the amount of $\mathrm{Ni}$ in crude and deodorized sunflower oil as $0.17 \mathrm{ppm}$ and $0 \mathrm{ppm}$, Güleç (2013); determined that $\mathrm{Cr}$ content in natural virgin olive oils ranged between $134.78 \pm 1.58-534.27 \pm 1.58 \mathrm{ng} / \mathrm{mL}$.

On the other hand, while the average $\mathrm{Cu}$ element value in crude corn oil samples was $0.148 \mathrm{ppm}$, as a result of refining, it decreased by $47.3 \%$ compared to crude corn oil and was found to be $0.078 \mathrm{ppm}$ in deodorized corn oil. It is seen that degumming-neutralization phase has the biggest effect. As a result of analysis of variance, the differences formed by refining were found to be statistically significant ( $\mathrm{P}<0.01)$. Küçükkolbaşı et al. (2014) determined the $\mathrm{Cu}$ element content of refined corn oil as $0.018 \mathrm{ppm}$ with $99.84 \%$ decrease with refining process. Bakırcığlu et al. (2013) determined values in the range of 0,568-1,658 ppm in refined corn oil, which is considerably higher than our results. Karayiğit (2018) determined the amount of $\mathrm{Cu}$ in crude and deodorized sunflower oil as $0.01 \mathrm{ppm}$ and 0.25 ppm. $\mathrm{Cu}$, which has a wide range of uses, is released into the environment with industrial powders, mineral enrichment and wastewater. The feeding of fertilizers of animals fed with $\mathrm{Cu}$ additives into the soil also leads to $\mathrm{Cu}$ accumulation (Haktanır and Arcak, 1998).

It is stated that the number of elements are quite high in different plant organs, the number of different elements reaches 60 , and a significant part of these elements is absolutely necessary for the development of plants. The soil structure and climate conditions where the plant is grown, the storage conditions of the product, the crude oil processing conditions of the oil source and the food processing equipment used are effective on the element content in the crude oils obtained from oil seeds and oily fruits (Taşan, 1999; Güler, 2009; Yüksel, 2010).

On the other hand, trace metals are among the most common environmental pollutants, and heavy metals, which can be found in different proportions in soil, water and air, cause pollution above a certain concentration (Tuna, 2011). In addition to the health risks they cause, heavy metals in oil break down the hydroperoxides in the fatty acid chain, allowing the formation of free hydrogen and hydroxyl ions in the environment. The ions formed cause the formation of new active radicals in the chain (Başoğlu, 2006). For these reasons, it is necessary to determine the amount of especially heavy metals in edible vegetable oils in order to prevent situations that may pose a health hazard.

\section{Conclusions}

The results of the study revealed that the chemical refining process applied to crude corn oil had a positive effect on the physicochemical properties of corn oil. The refining process applied; it ensured that the color value of corn oil was illuminated to a level that can be liked by the consumer, it lowered the free fatty acid value, which negatively affected the durability of the oil, to the desired levels, and the peroxide value has been reduced far below the legal limits accepted by the chemical refining process applied. It has been observed that the fatty acids determined in the fatty acid composition of the crude corn oil are preserved by taking part in the legal limits at the end of the refining process. The values of all the elements studied showed a decrease in different rates compared to crude corn oil with the effect of refining. The refining processes are effective in reducing the amounts of heavy metals, and in this respect, it can be seen that the refining has a positive effect on reducing the risk of health by decreasing the relatively heavy metal values of vegetable oils, and the adverse effects of the oxidative stability that may be caused by these metals can be prevented to some extent. These results reveal the necessity to control various element contents in oil sources to be used in refined oil production, oil seeds and oily fruits and crude oils obtained from them. It is imperative that heavy metals, which cause important health problems, are constantly monitored in vegetable oil products and more effective legal regulations are implemented.

\section{References}

Ali H, Khan E, Sajad MA. 2013. Phytoremediation of heavy metals-concepts and applications. Chemosphere, 91: 869881. https://doi.org/10.1016/j.chemosphere.2013.01.075

Angioni A, Cabitza M, Russo MT, Caboni P. 2006. Influence of olive cultivars and period of harvest on the contents of $\mathrm{Cu}$, $\mathrm{Cd}, \mathrm{Pb}$ and $\mathrm{Zn}$ in virgin olive oils. Food Chemistry, 99: 525529. https://doi.org/10.1016/j.foodchem.2005.08.016

Anonymous. 1987. IUPAC-Standard methods fort the analysis of oils, fats and derivatives, edited by C.Paquot and A.Hautfenne, 7th edn., Blackwell Scientific Publications Ltd., Oxford, London.

Anonymous. 1990. Animal and vegetable oils color determination by lovibond colorimeter. Turkish Standard 7959, Turkish Standards Institute, Ankara.

Anonymous. 2002. Agilent $6890 \mathrm{~N}$ series gas chromatograph operating manual volume 1 general imformation. Chromatography and spectroscopy supplies reference guide. Agilent technologies printed in Germany. http://www.agilent.com/chem.

AOCS. 1992. Official methods and recommended practices of the American Oil Chemists' Society. $3^{\text {th }}$ edn., American Oil Chemists' Society, IL., Method Ce.2-66.

Arellano DB, Ribeiro APB, Saldivar SOS. 2019. Corn: Chemistry and technology. In: Saldivar SOS (editor). Corn History and Culture. UK, Elsevier Inc. pp. 593- 613. ISBN: 978-0-12811971-6 (print) 978-0-12-811886-3 (online).

Bakırcioğlu D, Kurtulus YB, Yurtsever S. 2013. Comparison of extraction induced by emulsion breaking, ultrasonic extraction and wet digestion procedures for determination of metals in edible oil samples in Turkey using ICP-OES. Food Chem., 138: 770. https://doi.org/10.1016/j.foodchem.2012.10.089

Başoğlu F. 2006. Edible Oil Technologies. Nobel Publication Distribution, Ankara. ISBN: 9789755919422 
Chewa SC, Tanb CP, Longc K, Nyama KL. 2016. Effect of chemical refining on the quality of kenaf (hibiscus cannabinus) seed oil. Industrial Crops and Products, 89: 59 65. https://doi.org/10.1016/j.indcrop.2016.05.002

Çalışkan T. 2008. Effects of refining procedures on the isomer formation and oxidative stability of vegetable oils. MSc Thesis, Institute of Natural and Applied Sciences, Ankara University, Ankara, Turkey.

Das K, Das S, Dhundasi S. 2008. Nickel, its adverse health effects \& oxidative stress. Indian Journal of Medical Research, 128: 412-425.

Drira M, Jabeur H, Marrakchi F, Bouaziz M. 2018. Delta-7stigmastenol: quantification and isomeric formation during chemical refining of olive pomace oil and optimization of the neutralization step. European Food Research and Technology, 244: 2231-2241. https://doi.org/10.1007/ s00217-018-3132-2

FAO, 2018. FAOSTAT, FAO Statistical Databases. Available from: http://apps.fao.org/. [Accessed 2 February 2018]

Güleç A. 2013. A study on evaluation of heavy metal contents of extra virgin olive oil which are produced by organic and conventional agricultural methods in Turkey. PhD Dissertation. Institute of Health Sciences, Hacettepe University, Ankara, Turkey.

Güler G. 2009. Comparison of some physical and chemical properties of canola (rapeseed) oil obtained by cold pressing and chemical refining. MSc Thesis, Institute of Natural and Applied Sciences, Namık Kemal University, Tekirdağ, Turkey.

Haktanır K, Arcak S. 1998. Environmental pollution. Ankara University Faculty of Agriculture Publications, Ankara.

Jiang X, Jin Q, Wu S, Wang X. 2015. Contribution of phospholipids to the formation of fishy offodor and oxidative stability of soybean oil. Eur. J. Lipid Sci. Technol., 118: 603611. https://doi.org/10.1002/ejlt.201400408

Kabaran S. 2015. A study intended to examine the possible heavy metal intake from olive oils produced in güzelyurt area, KKTC. PhD Dissertation. University of Hacettepe, Institute of Health Sciences, Hacettepe University, Ankara, Turkey.

Karaali A. 1981. Changes in the composition of sunflower oil during refining. PhD Dissertation. Institute of Natural and Applied Sciences, Ege University, İzmir, Turkey.

Karayiğit 2018. The detectıon of impurities in nanoscale and physico-chemical changes occuring in refined stages of sunflower oil. MSc Thesis, Institute of Natural and Applied Sciences, Afyon Kocatepe University, Afyon, Turkey.

Kostik V, Memeti S, Bauer B. 2013. Fatty acid composition of edible oils and fats. J. Hyg. Eng. Des., 4: 112-116.

Kuleaşan Ş. 2004. Research on the support usage in neutralızation of crude oils. MSc Thesis, Institute of Natural and Applied Sciences, Ankara University, Ankara, Turkey.

Küçükkolbaşı S, Temur O, Kara H. 2014. Monitoring of Zn(II), $\mathrm{Cd}(\mathrm{II}), \mathrm{Pb}(\mathrm{II})$ and $\mathrm{Cu}$ (II) During Refining of Some Vegetable Oils Using Differential Pulse Anodic Stripping Voltammetry. Food Anal. Methods, 7: 872-878. https://doi.org/10.1007/s12161-013-9694-5

Lara SG, Saldivar SOS. 2019. Corn: Chemistry and technology. In: Saldivar SOS (editor). Corn History and Culture. UK, Elsevier Inc. pp. 1-18. https://doi.org/10.1016/B978-0-12811971-6.00001-2
Liu R, Guo X, Cheng M, Zheng L, Gong M, Chang M, Jin Q, Wang X. 2019a. Effects of chemical refinement on the quality of coconut oil. J. Food Sci. Technology, 56: 3109-3116. https://doi.org/10.1007/s13197-019-03810-w

Liu R, Liu R, Shi L, Zhang Z, Zhang T, Lu M, Chang M, Jin Q, Wang X. 2019b. Effect of refining process on physicochemical parameters, chemical compositions and in vitro antioxidant activities of rice bran oil. LWT - Food Science and Technology, 109: 26-32. https://doi.org/ 10.1016/j.lwt.2019.03.096

Martinez EJL, Ortega-Barrales P, Fernandez de Cordova ML, Dominguez-Vidal A, Ruiz- Medina A. 2011. Food Chemistry, 127: 1257-1262. https://doi.org/10.1016/j.foodchem.2011.01.064

Mudipalli A. 2008. Metals (Micro nutrients or toxicants) \& Global Health. Indian Journal of Medical Research, 128: 331334.

Nas S, Gökalp HY, Ünsal M. 2001. Vegetable Oil Technology. Pamukkale University Faculty of Engineering Textbooks. Denizli.

NMKL. 2011. Nordisk metoddikomitté for næringsmidler, National Veterinary Institue- Oslo, Norwegia; http://www.nmkl.org.

O'Brien RD. 2008. Fats and Oils - Formulating and Processing for Applications. CRC Press, New York, NY. https://doi.org/10.1201/9781420061673

Soysal Mİ. 1998. Basic principles of biometry. Trakya University, Faculty of Agriculture Publications, Tekirdağ.

Taşan M. 1999. Effects of different refining methods (chemical and physical) on the composition and oxidative stability of sunflower oil. PhD Dissertation. Institute of Natural and Applied Sciences, Trakya University, Tekirdağ, Turkey.

Taşan M, Demirci M. 2003. Trans fatty acids in sunflower oil at different steps of refining. Journal of the American Oil Chemists' Society, 79: 825-828. https://doi.org/10.1007/ s11746-003-0779-9

Taşan M, Geçgel Ü, Demirci M. 2011. Effects of storage and industrial oilseed extraction methods on the some quality and stability characteristics of crude sunflower oil (Helianthus annuus L.). Grasas y Aceites, 62: 389-398. https://doi.org/10.3989/gya.126010

Taşan M, İmer Y. 2018. Determination of Some Micro and Macronutrient Elements in Various Cold Press Vegetable Oils. Journal of Tekirdag Agricultural Faculty, 15.

Tuna B. 2011. Determination of some heavy metals and micronutrient elements in olives grown in the Sarkoy region. MSc Thesis, Institute of Natural and Applied Sciences, Namık Kemal University, Tekirdağ, Turkey.

Xie D, Zhou H, Jiang X. 2019. Effect of chemical refining on the levels of bioactive components and hazardous substances in soybean oil. Journal of Food Measurement and Characterization, 13: 1423-1430. https://doi.org/10.1007/ s11694-019-00058-y

Yüksel E. 2010. Various determination of the levels of some element in refined vegetable oils and margarines produced in Turkey. MSc Thesis, Institute of Natural and Applied Sciences, Namık Kemal University, Tekirdağ, Turkey.

Zhu M, Wen X, Zhao J, Liu F, Ni Y, Ma L, Li J. 2015. Effect of Industrial Chemical Refining on the Physicochemical Properties and the Bioactive Minor Components of Peanut Oil. J. Am. Oil Chem. Soc., 93: 285-294. https://doi.org/ 10.1007/s11746-015-2776-3 